\title{
СИСТЕМА ВІЗУАЛІЗАЦІЇ РОБОТИ ПИЛОВЛОВЛЮЮЧОЇ УСТАНОВКИ 3 КОНТРОЛЕМ III ОСНОВНИХ ТЕХНОЛОГІЧНИХ ПАРАМЕТРІВ В УМОВАХ ЦЕМЕНТНОГО ВИРОБНИЦТВА
}

\author{
Сердюк О.Ю. - кандидат технічних наук, \\ старший викладач кафедри автоматизації, комп'ютерних наук і технологій \\ Криворізького національного університету \\ ORCID ID: 0000-0003-0505-0800 \\ Маринич I.A. - кандидат технічних наук, \\ доцент кафедри автоматизації, комп'ютерних наук і технологій \\ Криворізького національного університету \\ ORCID ID: 0000-0002-9036-8532
}

Стаття присвячена дослідженню технологічного прочесу очищення газів від пилу електрофільтрами в умовах иементного виробництва з метою розробки автоматизованої системи контролю та візуалізації технологічних параметрів, щуо дає змогу контролювати процес у режимі реального часу, вчасно визначити аварійні ситуацї. Це питання $\epsilon$ актуальним з огляду на те, шо иементна промисловість з кожним роком збільиує свою виробничу потужність, а зменшення викидів в атмосферу запилених та отруйних газів дозволить уникнути виплати штрафів та зменшити виплати за шкідливі викиди. Для досягнення поставленої мети було проаналізовано технологічний процес і роботу наявної системи управління обезпиленням газів та визначено, шуо июю систему можна вдосконалити шляхом застосування нових підходів і методів управління та візуалізації роботи самої системи у режимі реального часу. Досліджено схему руху часток в електрофільтрі та схему руху газу під дією електричного вітру, на основі цьього аналізу виконано математичний опис технологічного процесу та розроблено алгоритми керування струшуванням, в якому передбачено корекцію сили струшування, щзо дає змогу проводити ефективні струшування з мінімальним руйнуванням обладнання електрофільтра. Розроблена система контролю та візуалізації відповідає трирівневій структурі, де на першому рівні виконується вимірювання параметрів технологічного прочесу, на другому реалізується логічне управління механізмами згідно алгоритмів керування, а на третьому відбувається взаємодія системи управління з операторами, накопичується та обробляється архівна та оперативна інформація про стан обладнання. Практичне значення полягає в застосуванні отриманої автоматизованої системи контролю та візуалізаиії основних технологічних параметрів для отримання оперативної інформації у реальному часі як самого технологічного процесу, так і оптимізації режиму струшування електродів при очищенні газів холодного кінияя печі від пилу в електрофільтрі.

Ключові слова: візуалізачія, електрофільтр, коронуючі та осаджувальні електроди, очищення газів, ПЛК, система керування.

Serdiuk O.Y., Marynych I.A. Visualization system of dust collection equipment operation with control of its main technological parameters in conditions of cement production

Article is devoted to study of gas purification technological process by electrofilters in conditions of cement production in order to develop automated control system and technological parameters visualization, which allows to control process in real time, to identify emergencies. This issue is urgent task given that cement industry is increasing its production capacity every year, and reducing emissions of dusty and toxic gases will avoid paying fines and reduce emissions payments. To achieve this goal was analyzed technological process and existing gas dedusting control system operation and it is determined that the existing system can be improved by applying new approaches and methods of control and visualization of system 's work by itself in real time. Scheme of particle motion in electrofilter and scheme of gas motion under the action of electric wind are investigated, on basis of which technological process mathematical description was executed and shaking control in which correction of shaking force that allows 
to carry out effective shaking at minimum destruction of electrostatic precipitator equipment. The developed control and visualization system corresponds to three-level structure, where at the first level technological process parameters are measured, at the second level logical control of mechanisms according to control algorithms is realized, and at the third level control system interacts with operators, collected and processed and archived online information about status of equipment. The practical significance lies in application of automated control system and visualization of main technological parameters to obtain real-time operational information as process itself, and to optimize electrodes shaking mode when cleaning the gases of cold end of furnace from dust in electrofilter.

Key words: visualization, electrofilter, crowning and sediment electrodes, gas purification, plc, control system.

Вступ. Одним із головних джерел виділення пилу в виробництві цементу і забруднення повітряного басейну є гази, що відходять від обертових печей обжигу клінкеру. Величина співвідношення пилу з газами залежить від багатьох факторів та може досягати $25 \%$ від ваги шихти.

Зважаючи на характеристики пічних газів та технологічні умови виробництва, для очищення використовуються електрофільтри. Під час проходження запиленого газового потоку через потужне електричне поле частки пилу отримують електричний заряд та прискорення, що змушують їх рухатись уздовж силових ліній поля з подальшим осадженням на осаджуваних електродах. Отже, агрегат живлення фільтру є компонентом, важливим для його якісної роботи. Для видалення пилу з осаджуваних електродів необхідно виконувати струси зі значним прискоренням. Але це суперечить необхідності забезпечення надійності та довговічності обладнання електрофільтрів. Розв'язання цього завдання допоможе значною мірою покращити процес фільтрації та запобігти передчасному виходу зі строю обладнання.

Постановка проблеми. За останні роки техніка пиловловлення на промисловості постійно вдосконалювалась, і комплекс пиловловлюючих апаратів, що застосовується сьогодні, дає змогу отримати за умови правильної його експлуатації цілком задовільний ефект. Однак досягненні результати не можуть вважатися граничними. Це підтверджується кількома факторами.

По-перше, цементна промисловість з кожним роком збільшує свою виробничу потужність, при цьому ріст досягається головним чином за рахунок підвищення випуску продукції шляхом удосконалення діючих агрегатів. Таким чином, зі зростанням продуктивності агрегатів зросте й абсолютна кількість уловленого пилу, а тому підвищення ступеня фільтрації очисних пристроїв навіть на долю відсотка буде сприяти підвищенню якості продукції, що виготовляється, на величину, що оцінюється мільйонами гривень.

По-друге, вдосконалення техніки обезпилення диктується вимогами охорони здоров'я людей і природи, що виражається положеннями санітарного законодавства України, сформульованих у санітарних нормах проектування промислових підприємств.

По-третє, виконання вимог санітарного законодавства та зменшення викидів в атмосферу запилених та отруйних газів (таких як сполуки азоту, окиси сірки, окис вуглецю) допоможе уникнути виплати штрафів, які досягають сотень тисяч гривень, та зменшити виплати за шкідливі викиди.

Таким чином, дослідження питань процесу очищення газів холодного кінця печі від пилу в електрофільтрі, пов'язаних з розробкою системи контролю та візуалізації технологічних параметрів, що дає змогу контролювати процес в режимі реального часу, вчасно визначити аварійні ситуації є актуальним завданням. 
Аналіз останніх досліджень і публікацій. Для виявлення недоліків роботи наявної системи та знаходження оптимальних інженерних рішень були досліджені різні типи промислових електрофільтрів [1; 2]. На сьогодні найбільшого поширення набули електрофільтри серій УГ, ЕГА, УГТ, УВ та ДМ, що відрізняються між собою типом розташування електродів (горизонтальне або вертикальне) та рівнем температури газів, що очищуються. Для оптимізації роботи таких фільтрів використовують різні системи, наприклад, такі як система автоматичної підтримки напруги в межах пробивної та зниженої на задану величину [3], система автоматичного регулювання напруги за частотою іскрових розрядів в електрофільтрі [4], система автоматичного регулювання напруги шляхом фіксації та підтримки на електродах максимальної середньої напруги. Слід зазначити, що такі системи не дають необхідної інформації про стан обладнання у реальному часі та потребують значних фінансових ресурсів, тому доцільніше вдосконалити наявні системи шляхом розробки системи візуалізації та контролю її технологічних параметрів.

Виклад основного матеріалу досліджень. У результаті проведеного аналізу роботи чинної системи управління системою обезпилення газів в умовах Криворізького цементного комбінату визначено, що установку можна вдосконалити шляхом застосування нових підходів та методів в очищенні газів. Дослідження різних типів промислових електрофільтрів дало можливість виявити найкращі способи роботи, характеристики обладнання, та технологічні параметри, що можуть бути досягнені в оптимізованій системі керування. Вибір агрегату живлення електрофільтру 3 автоматичним керуванням є важливою проблемою при вдосконаленні системи. Окрім того, що від його якісної роботи безпосередньо залежить якість вихідного продукту процесу фільтрації, агрегат живлення повинен бути ретельно вибраним для максимального спрощення структури та математичного забезпечення розроблюваної системи.

Розрахунок процесу електричної очистки газів від завислих часток можна розділити на 3 стадії:

- розрахунок зарядки завислих часток;

- визначення руху заряджених часток до осаджувальних електродів під дією сил електричного поля;

- осадження на електродах заряджених рухомих частинок.

Зарядка великої частки відбувається до стану, в якому сумарне електричне поле у всієї її поверхні стає близьким до нуля.

Як показали розрахунки Патеньє і Моро-Ано [3], до того часу частка отримує максимальний заряд (в К):

$$
q_{м}=n e=4 \pi \varepsilon_{0}\left(1+2 \frac{\varepsilon-1}{\varepsilon+2}\right) E_{3} r^{2}=4 \pi \varepsilon_{0} \delta E_{3} r^{2}
$$

де $n$ - число елементарних зарядів; $e$ - величина заряду електрона, К; $\varepsilon_{0}$ - діелектрична проникність вакууму або електрична стала, Ф/м.; $\varepsilon$ - відносна діелектрична проникність речовини частки; $\delta$ - показник діелектричних властивостей частки; $E_{3}$ - напруженість електричного поля коронного розряду в області проходження частки, В/м; $r$ - радіус частки, м.

В електричному полі коронного розряду великі частки заряджаються іонами, що рухаються під дією сил електричного поля, а дрібні частки - іонами, що беруть участь у тепловому русі газових молекул. Зависла в газах частка, надходячи в електрофільтр, здобуває електричний заряд, що досягає значення, близького до 
максимального, за дуже малу частину секунди. Оскільки частка в полі електрофільтру звичайно перебуває протягом декількох секунд, можна вважати, що заряд іiї в електрофільтрі має постійне, таке, що не залежить від часу, значення (обумовлене величиною частки й напруженістю електричного поля).

Механічний вплив потоку іонів на молекули газу в електричному полі, що викликає рух газу в напрямку до осаджувального електрода, зветься електричним вітром. Електричний вітер виникає при розряді з вістря і починається від коронуючих точок (Рис. 1).

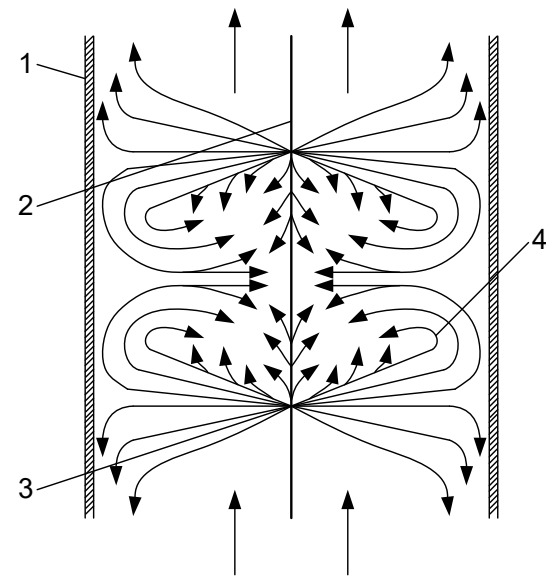

1 - осаджувальний електрод; 2 - коронуючий електрод;

3 - коронуюча точка; 4 - траєкторії руху молекул газу.

Рис. 1. Схема руху газу під дією електричного вітру

Основною силою, що діє на частку в електрофільтрі, є кулонівська сила дії електричного поля на заряд частки (у Н) [1]:

$$
F=q_{M} E_{o c}=n e E_{o c}=4 \pi \varepsilon_{0} E_{3} E_{o c} r^{2} \delta
$$

де $E_{\text {ос }}$ - напруженість електричного поля осадження, В/м; $E_{3}-$ напруженість електричного поля зарядки, В/м; $n$ - число елементарних зарядів на частці; $e$ - заряд електрону, к; $r$ - радіус частки, м; $\delta$ - показник діелектричних властивостей частки.

Ця сила поза областю корони спрямована до осаджувального електроду. В області ж корони деякі частки заряджаються позитивно і рухаються до коронуючого електрода. Частки осаджуються на електродах електрофільтру під впливом сил електричного поля. Основна кількість часток осаджується на поверхні осаджувальних електродів. Осадження заряджених часток залежить від багатьох факторів: провідності й розміру часток, швидкості газів, їхньої температури і вологості, стану поверхні осаджувальних електродів тощо.

Для видалення пилу з осаджувальних електродів необхідно виконувати струси зі значним прискоренням. Але це суперечить необхідності забезпечення надійності та довговічності обладнання електрофільтрів. Тому дуже важливо знайти оптимальні режими струшування пилу, що залежать від фізико-хімічних властивостей пилу, а отже, від його здатності до осаджування на електродах. Зазвичай ці режими визначаються експериментальним шляхом. Очевидно, для підвищення 
надійності роботи електрофільтра та зниження вторинного віднесення пилу за постійних показників забрудненості повітря та властивостей часток струшування повинно проводитися періодично [5]. У випадку змінного процесу забруднення цей метод не буде виправдовувати себе: або газ не фільтруватиметься належним чином, або відбуватиметься часте струшування і як наслідок - передчасний вихід з ладу обладнання, що піддається впливу вібрацій. Також метод не враховує нерівномірність осідання пилу на електродах залежно від місця розташування: на електродах, що знаходяться в передній частині робочої камери фільтру, пилу осідатиме більше, ніж на тих, що розташовані в задній частині. Розв'язанням цих завдань може бути визначення маси пилу, що осів на електроді, за допомогою тензодатчика. Сигнал з датчика надходить до промислового контролера, який у разі досягнення встановленої межі приводить у дію виконавчий механізм і відбувається струшування.

Осаджувальні електроди обтрушуються шляхом передання їм такого збурюючого зусилля, що здатне відірвати шар пилу, накопичений на поверхні електрода. За більших прискорень, що надаються електроду, очищення його поверхні відбувається краще. Однак це призводить до механічних ушкоджень самих електродів та систем їх підвішування. Пошуки оптимального розв'язання проблеми призвели до розробки великої кількості систем та механізмів обтрушування. На практиці широкого застосування набули системи ударно-молоткової дії, пневматичні, магнітно-імпульсні та вібраційні [1].

У результаті аналізу схеми руху часток в електрофільтрі та схеми руху газу під дією електричного вітру, на основі якого було виконано математичний опис технологічного процесу, застосовано метод струшування осаджувальних електродів, що базується на визначенні зміни ваги електродів за рахунок осадженого пилу. Розроблений алгоритм керування струшуванням (Рис. 2), в якому передбачено корекцію сили струшування, що надає можливість проводити ефективні струшування з мінімальним руйнуванням обладнання електрофільтра.

Першим кроком в алгоритмі виконується завантаження параметрів системи, які були отримані під час попередньої роботи. Якщо програма виконує цикл уперше, то параметри можуть бути встановлені на середнє значення.

У блоці 3 відбувається опитування датчика. Отримана величина ваги порівнюється із встановленим граничним значенням. Якщо вага перевищує встановлену, то кількість пилу на електродах досягла тієї величини, коли її потрібно струшувати. Формуються вихідні керуючі впливи: імпульс та сила удару. Після струшування знову знімається інформація з датчика та перевіряється, чи було струшено весь накопичений пил. Якщо вага, виміряна датчиком, перевищує вагу чистих електродів (блок 7), тобто сили удару не вистачило для повного очищення електроду, то збільшується величина сили удару (блок 8), інакше система переходить до наступного циклу. Перед вимкненням системи отримані параметри щодо сили удару зберігаються до енергонезалежної пам'яті контролера. Блоки 3-8 повторюються послідовно для кожного датчика. Сили удару для виконавчих механізмів повинні зберігатися в різних байтах.

Це обумовлено тим, що на різні електроди можливе осідання частинок пилу 3 різними властивостями, а отже, впливи мають різнитися між собою. Таким чином, в алгоритмі передбачено корекцію сили струшування, що дає змогу проводити ефективні струшування з мінімальним руйнуванням обладнання електрофільтра. 


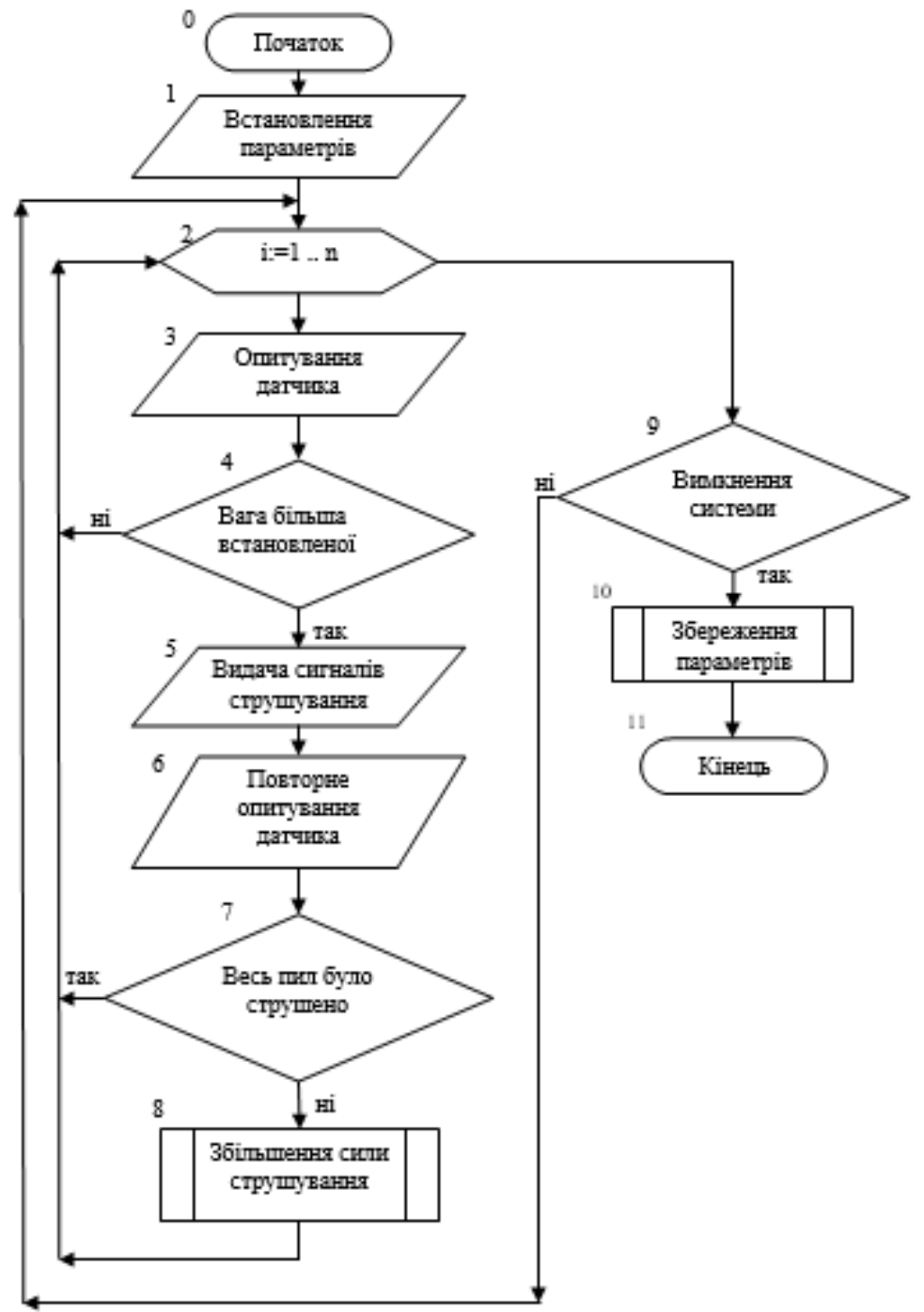

Рис. 2. Алгоритм керування струшуванням

Якщо струшування проводити занадто часто, то струшений пил буде забруднювати очищені гази. Для розв'язання такого завдання стане в нагоді алгоритм визначення режимів струшування (Рис. 3), який забезпечить виявлення оптимального режиму роботи механізму обтрушування електродів.

Система буде збільшувати критичну масу електродів, при якій відбувається струшування, від мінімальної до максимальної з визначеним кроком. Водночас реєструється запиленість очищених газів. Можливі випадки, коли залежно від фізико-хімічних властивостей пилу струшування необхідно проводити частіше, ніж звичайно. Якщо цього не робити, то осаджений пил буде змінювати електричне поле і процес очищення погіршиться, або матиме місце явище повторного уносу часток. 
44

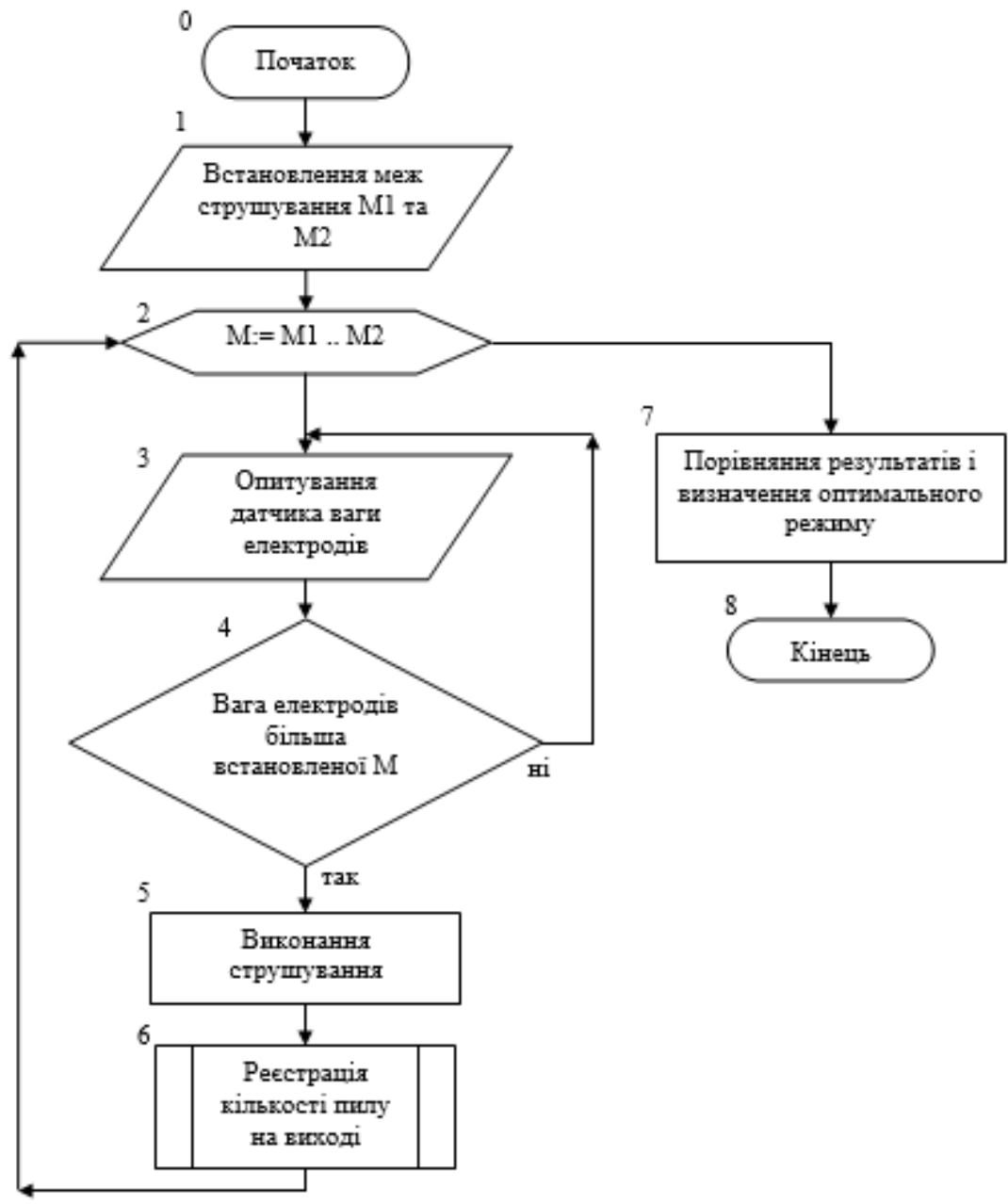

Рис. 3. Алгоритм визначення режимів струшування

Для реалізації АСУТП електрофільтра передбачається використання комплексу технічних засобів фірми Schneider Electric. Для комунікації апаратних засобів автоматики обрано протокол Unitelway. Його здатність працювати в різних сферах передачі даних, легкість при настроюванні та підтримка багатьма провідними виробниками стали переважними аргументами на користь цього протоколу. Для побудови SCADA-системи очищення газів від пилу в умовах ПАТ «ХайдельбергЦемент Украина» оптимальним рішенням є програмний додаток Monitor Pro [6].

На запропонованій екранній формі (Рис. 4) представлено основні вузли системи пиловловлення. Ліворуч розташована колонка охолодження газів, яка виконує зрошування газів водою для пониження їхньої температури та набуття ними потрібної вологості. Робота кожної форсунки відображається на екрані. 


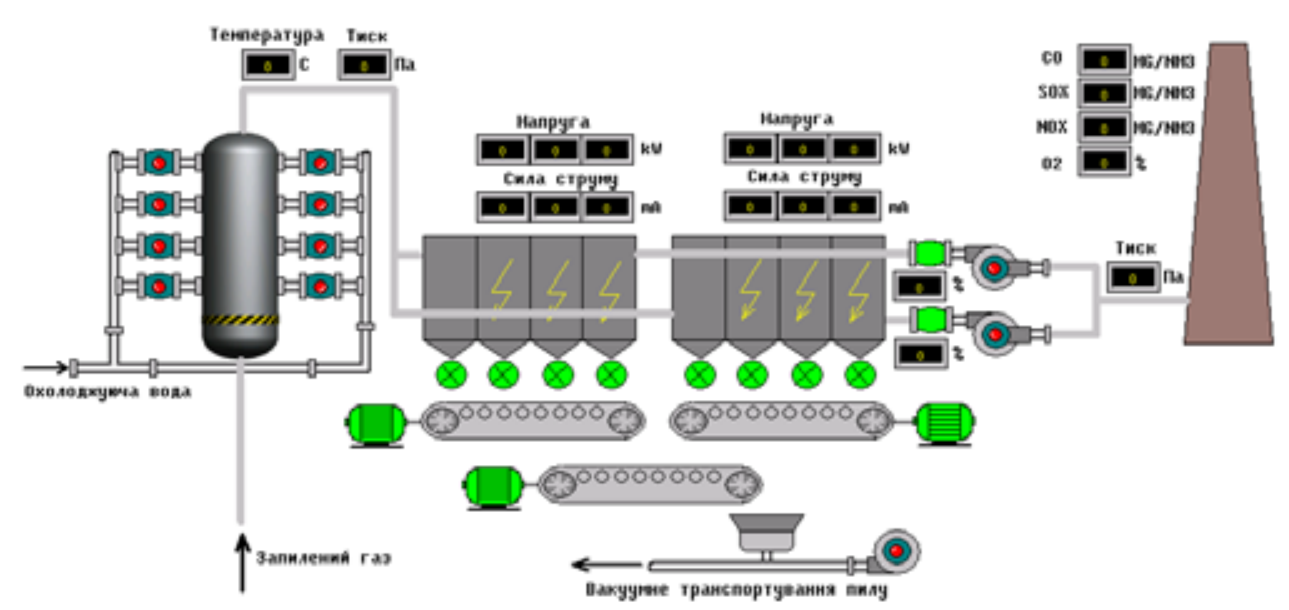

Рис. 4. Екранна форма програмного додатка

На вході в електрофільтри вимірюється температура та тиск газів. Відображується наруга та сила струму у кожному полі електрофільтра. Відбувається спостереження за роботою системи механізмів пиловидалення. На виході електрофільтрів розташовані кінцеві димососи, тяга яких регулюється процентним відношенням відкриття шиберів. Також вимірюється тиск газів після димососів. На екрані відображається робота димососів та процент відкриття шиберів. На виході газів в атмосферу встановлено зонд газоаналізатора. Останній передає інформацію для індикації про хімічний склад газів.

Незважаючи на те, що електрофільтри не можуть проводити хімічне очищення газів, індикація надмірного забруднення газами азоту та сірки важлива для своєчасного знаходження помилки в технології виготовлення цементу. Тож праворуч на формі відображається процентний вміст шкідливих речовин, що мають гранично допустиму концентрацію, в очищених газах. За необхідності дізнатися інформацію про стан шкідливих викидів за окремий проміжок часу на екран може бути викликаний тренд.

Висновки. Для побудови SCADA-системи очищення газів від пилу в умовах цементного виробництва оптимальним рішенням $\epsilon$ програмний додаток Monitor Pro. Потужні функціональні можливості, широка сфера застосування, переважна кількість сумісних апаратних засобів автоматики роблять Monitor Pro лідером у цій галузі. Однією з його важливих особливостей є можливість побудови інтегрованої бази даних роботи системи, на основі даних якої можна визначати оптимальні режими керування системою струшування електродів. Запропонована екранна форма дозволяє в режимі реального часу слідкувати за роботою механізмів системи та зміною технологічних параметрів

Система, створена на запропонованих апаратних рішеннях, дозволяє керувати технологічним процесом очищення газів від пилу в реальному масштабі часу. Вона забезпечує легку та зручну взаємодію технологічного персоналу стану з комплексом технічних засобів, спрощує процес управління та обслуговування. Впровадження системи дозволить покращити техніко-економічні показники роботи електрофільтру та вивести процес керування на якісно новий рівень. 


\section{СПИСОК ВИКОРИСТАНОЇ ЛІТЕРАТУРИ:}

1. Алиев Г.М., Гоник А.Е. Электрооборудование и режимы питания электрофильтров. Москва : Энергия, 1981. 264 с.

2. Бакланов Г.М., Перли С.Б., Эдельман И.Е. Снижение запыленности на цементных заводах. Киев : Будівельник, 1985. 93 с. 114 c.

3. Ганз С.Н. Очистка промышленных газов. Днепропетровск : Промінь, 1997.

4. Коровин В. Г. Системы программного управления промышленными установками и робототехническими комплексами. Санкт-Петербург : Промиздат, 2010. 197 c.

5. Перевезенцев А.В. Электрическая очистка газов в цементной промышленности. Москва : Издательство литературы по строительству, 1989. 112 с.

6. Ken Barnes, Briam Johnson, Reva Nickelson. Review of Supervisory Control and Data Acquisition (SCADA) Systems. Idaho National Engineering and Environmental Laboratory, 2004.

\section{REFERENCES:}

1. Aliev G.M., Gonik A.E. (1981) Elektrooborudovanie i rezhimy pitaniya elektrofil'trov [Electrical equipment and power supply modes of electrofilters]. Moskva: Energiya [in Russian].

2. Baklanov G.M., Perli S.B., Edel'man I.E. (1985) Snizhenie zapylennosti na cementnyh zavodah [Dust reduction in cement plants]. Kiev: Budivel'nik [in Ukrainian].

3. Ganz S.N. (1997) Ochistka promyshlennyh gazov [Purification of industrial gases]. Dnepropetrovsk: Promin' [in Ukrainian].

4. Korovin V. G. (2010) Sistemy programmnogo upravleniya promyshlennymi ustanovkami i robototekhnicheskimi kompleksami [Software control systems for industrial equipment and robotic complexes]. Sankt-Peterburg: Promizdat [in Russian].

5. Perevezencev A.V. (1989) Elektricheskaya ochistka gazov v cementnoj promyshlennosti [Electrical gas cleaning in the cement industry]. Moskva: Izdatel'stvo literatury po stroitel'stvu [in Russian].

6. Ken Barnes, Briam Johnson, Reva Nickelson. (2004) Review of Supervisory Control and Data Acquisition (SCADA) Systems. Idaho National Engineering and Environmental Laboratory. 